\title{
Urbanization and Diversification
}

\author{
ARUADSU
}

\begin{abstract}
The urbanization process in Namlea village is a consequence of the change in the administrative status of Buru regency into a district. The phenomenon of change affects the social economic life of the community, such as kinship patterns and interaction patterns that shift from homegenous to heterogeneous traits. The research location focuses on the village of Namlea in consideration of changes in community structure and the reduction of agricultural land. The number of informers interviewed were as many as farmers, village apparatus, religious figures, community leaders as well as traders. Analytical techniques used to follow the concept of Miles and Huberman where activities in the analysis of qualitative data are conducted interactively and continuously. The results showed that the urbanization process has brought about the impact of changes in the fulfillment of life needs in which life orientation shifts from agriculture to nonagriculture. Diversification is the basis for increasing the value of land selling and the limitation of agricultural products as a result of the increasing number of needs that are not followed by the improvement of land resources and agricultural products.
\end{abstract}

Keywords: Namlea, Conversion, Farmland, Village, Buru

\section{INTRODUCTION}

The development of rural areas in support of regional development becomes so important in the era of decentralization, almost most rural areas in Indonesia continue to be developed for the achievement of community welfare[1]. Along with the achievement of the community, the presence of Namlea village as one of the supporting village of the capital of Buru Regency will be born also various problems as a logical consequence of rural dynamics into urban, so that the condition The change is expected to be the direction and end destination of the community welfare of Namlea village[2].

Namlea subdistrict is the capital of Buru Regency consisting of 11 villages and 9 hamlets. The area of Namlea subdistrict is $226.55 \mathrm{Km}$. Residents of Namlea sub-district according to the data of the Central Bureau of Statistics in 2017 are 34,326 inhabitants (Central statistics agency, 2018)[3]. In the meantime, Namlea village is one of the villages in Namlea district has an area of $12 \mathrm{Km} 2$ and a population of 26757 people with a population growth of 6.26 per year[4]. The phenomenon of Urbanization in Namlea village can be understood by the availability of economic facilities and infrastructure and government infrastructures that are entirely in the administrative area of Namlea village[5], so it can be understood that land utilization will be more is dominated by infrastructure development and public housing[6].

The centralised population of Namlea village as a result of economic, social and governmental centration[7], making the needs of land every year continues to increase, including agricultural land which then many in conversion (rather than function) and diversification to fulfill daily necessities of life. Along with the development, the existence and existence of farmer's household is increasingly limited[8].

The transition of agricultural land into housing and offices as well as trading makes farmers increasingly difficult, even start to urge to exit and develop agriculture in a location that is of course with a distance farther than before[9][10]. Diversification becomes an interesting phenomenon when households as well as agricultural landlords begin to see the process of being made as a favorable condition. The changing of farmland became economic means of consideration for them in adapting to the changes in Namlea village.

Sudrajat in the analysis of his research showed farmers village Tambakrejo planting agricultural commodities paddy fields divided into 3 seasons. Planting Season 1 and 2 the majority of farmers in Tambakrejo village are producing rice crops[11]. While in the planting season 3 the majority of farmers Tambakrejo village to cultivate the land to be planted with types of agricultural commodities such as corn, tobacco, chili, cassava, peanut, melon, Watermelon. Meanwhile, Ndawa from his research to get analysis on the change of land area influence the change of livelihoods of farmers due to daily labor absorption in the agriculture sector shrinking as the area of land ownership of farmers[12]. It is evidenced that a decrease in land area of $1 \mathrm{Ha}$ has an impact on the decline in agricultural sector use by 0.75 people[13]. This daily labor depreciation causes farmers to diversify their farming. Those who originally only rely on living only from farming and breeding alone now other than farming and livestock they also manage the accommodation in the form of homestays and rental rooms[14].

This research was conducted based on the preference of the urbanization process in Namlea village as well as the diversification of agricultural land as a consequence of the urbanization process occurring[15]. In addition, the research aims to get a primer on the diversification patterns and the impacts of farmers ' households and agricultural landlords in Namlea village.

\section{LITERATURE REVIEW}

\subsection{Urbanization Process}

In the process of urban development does not release the concept of urbanization. Urbanization is an urbanization process[16]. Urbanization is not merely the centralization and growth of population, but also involves various commercial factors, especially related to the specialization of work[17], communication development, recreation, and so forth [8]. The process of developing a city is not merely a matter of population, but it is far related to the urbanisation process that occurs in a region and affects people living in the region[18].

The increasing population growth and urban activities increased the incidence of land demand. There is a need for shelter to 
encourage the increase of land price increases.

Urbanization can be interpreted as a village urbanization process[19][20]. Urbanization is a process of increasing proportion of people living in urban areas. A process that is driven by structural changes in the community so that the area of the first country is a rural area with an agrarian livelihood structure and the nature of other slow society life or through a fundamental process Gaining the nature of city life. The urbanization process can be interpreted in two senses[21]. is an essential change in the physical and socio-economic area of the region because of the acceleration of economic progress, many people who moved from the village to the city due to the city's pullers, e.g. job opportunities[22].

Generally the urbanization process will occur continuously and will result in the increasing size of a region, from rural to urban, from the urban will be the metropolis and eventually will become Mega Urban[23]. In the mega urban phase of the city will experience a point of culination, which when this development is forwarded the city will become like garbage, in which phase the city is filled with humans with all its activities[24]. Urbanization is a process that is driven by structural changes in the community, so that the area that used to be a rural area with an agrarian livelihood structure and the life nature of the people gradually or Through a sudden process of gaining the nature of city life.

\subsection{Diversification of Land}

The definition of land use according to Arsyad is every form of human intervention (interference) to land in order to fulfill the needs of his life both material and spiritual[25]. There are two large types of land use namely agricultural land utilization and non-agricultural land utilization. Optimal land utilization requires linkage with the characteristic and quality of its grounds[26]. This is due to limitations in land utilization that correspond with the characteristics and quality of the land when connected with the use of sustainable lands[27]. Diversification can simply be interpreted as activities or actions to make things become more diverse or not fixed in just one type. In the business world, this diversification is often identified with the phrase "not putting eggs in one basket"[28].

Land utilization for agriculture has dynamic and varied properties according to time, place, and in line with the development of unlimited life needs as well as ability to manipulate the geological condition of land[29]. This dynamic trait affects the existence of land utilization for agriculture in an area. Land utilization is often different or even contrary to the potential of its lands, so it can impact disaster. In the agriculture sector, diversification means allocating agricultural resources to several other activities that are economically and environmentally beneficial[30]. These agricultural resources can be in the form of farmland, buildings (stables, barns, house plants, etc.), agricultural machinery, to other agricultural inputs such as fertilizer.

\section{Method}

The research was conducted in Namlea village, Namlea subdistrict, Buru regency. The determination of the research site was conducted purposive[31] with the consideration that Namlea village was chosen as a research site because it has a large percentage of agricultural land compared to other villages in the district Namlea. The number of informant that will be interviewed as many as 25 people taken in purposive [16] In consideration of informant is considered as related parties to achieve research objectives[32]. The informant is a village apparatus, a farmer, a religious figure, a community leader and a trader.

The data on this research is derived from primary data sources and secondary data, with data collection techniques used through observations, interviews, questionnaire and library studies [18]. In the step of the interview researchers conducted a thorough interview with the informant[33] and made a direct observation of all activities conducted by the informant. Researchers also sought complementary information related to the diversification of agricultural land in Namlea village through discussions with informant at the site[34]. The interview was conducted at 17.00-22.00 where the researchers adjusted the working time and the rest of each informant.

The analytical techniques used in this study are the analysis of qualitative data following the proposed concept of Miles and Huberman and Spradley[35][36]. Miles and Huberman, suggests that activities in the analysis of qualitative data are conducted interactively and ongoing continuously at every stage of the research so as to complete and data until saturated[37]. Activity in data analysis i.e. data reduction, data presentation, withdrawal of conclusions.

\section{Result}

\subsection{Sosial Economic Condition of Village Community Namlea}

Generally, people who inhabit the area of Namlea village are characteristic of village people who have undergone rapid changes in the development process that took place in Buru Regency. One of the main causes of change is the location of Namlea village which is the center of the capital of Buru Regency. Increasing the population, increasing the level of education and the need to open the type of work in the service sector, make Namlea village more rapidly the change to the formation of a small town.

In development, the village of Namlea can be seen through growth indices and development of rural communities we can observe in some of the following data

Table 1 shows the increasing population of Namlea village in the last 4 years. The most population increase took place in 2017 of 415 inhabitants. The average number of people added is 208 inhabitants. The addition of the population increased the rate of 
need for housing and household needs.

The consequence of increasing population is a change in various sectors of social economic life of village society. The changes can be seen in each decade as described in the following table.

Table 2 shows the change of social Economic Community Namlea Village where the change was divided into 3 decades. In 2000, being the beginning of change, migration from several areas around the island Buru and changes in the administrative status changed the structure of the community and eliminated the dominance of indigenous peoples[38]. Year 2010, change of infrastructure and availability of resources to change the order of occupancy and the building of Group awareness based on ethnic and ethnic groups, in 2019 society increased the level of education and development and exploration Opportunities and resources available in the village of Namlea.

The shifts and changes that have occurred have an impact on the whole community in Namlea village. In understanding the changes, the community understands in several different contexts according to the background as well as the orientation they have as summarized in the table below.

In table 3 There are some views that have optimism and some still think that the development and the changes made have not completely positive impact. In the village apparatus segment, optimism seen from the increase of population and social economic change of society which is considered increasingly conducive and able to create a multicultural tolerance and kinship[39]. Community leaders have an optimistic view when society changes are able to be supported by the Government through policies and regulations. Meanwhile, segments of public figures are concerned about the increase of population and the development that is done will produce competition and conflict in society. Segment traders have the view that population

increase must be followed development
change and need to be regulated about the competition in addressing the increase of trade and competition of the business world.

\subsection{Diversification of Land in Namlea Village}

The success of agricultural development, closely linked with the geographical factors of physical factor and non physical factors. Physical factors, such as fertile land, supportive climate, and adequate water source, while the non physical factor is in human beings themselves in the utilization of natural resources (among others, land processing, institutions, and Knowledge).

One of land utilization is the land function (conversion) of land. This phenomenon arises as the need and demand for land[40], both from the agricultural sector and from the agricultural sector as well as from the non-agricultural sector due to population and development activities.

Based on the results of the dissemination of a questionnaire conducted on 25 informant, the cause of change of agricultural land use from economic considerations, of which $84.6 \%$ of farmers changed land due to economic reasons. While $15.4 \%$ change agricultural land is not due to economic reasons, the other causes because of the large agricultural land belonging to farmers is inheritance (amounting to $69.1 \%$ ) And the other is the one who buys (amounting to $20.9 \%$ ).

Most farmers change their farms for economic reasons. Land owned farmers comes from inheritance and buying. As a farmer, the family was overcast so the farmers had no intention of abandoning his profession. In addition to the urgent needs. Farmers sell their farms because they get an offer from a community of migrants and are tempted by high land sale prices.

\section{Discussion}

The development of the Buru Regency became the starting point for the change of Namlea village, the change of community structure, infrastructure development and resource management to segmenting the main factor of social change in Namlea village. The people's condition that originated from homogeneous traits consisting of indigenous tribes and the surrounding population turned out to be heterogeneous due to the arrival of residents from surrounding areas with different social economic backgrounds. This phenomenon became two strengths for the development and change of social Economic community in Namlea Village[41][42]. In the first part, heterogeneous is able to be a driver in the provision of capital and development resources[43] so that the increase in population impacts on increased business and labour force[44].

Development is essentially a process of social economic change aimed at improving the living standards, quality of life and human benefits that are done intentionally with an action [45]. The public perception of the urbanization process is the highest percentage of community structure change. The community sees the change in structure to save problems such as group interest conflicts, the reference of resources until competition between tribes when population growth conditions are higher but not followed by the addition of economic resources[46].

The urbanization process occurs in the change of community structure as well as changes in the interaction pattern where the making element makes uniformity into heterogeneous and the society is increasingly polarized in the interest group and the origin area equation. Interaction patterns cause orientation to fulfill needs not based on natural resources but developed in business sectors that are not directly related to nature[47] so Namlea village community is no longer a community structure that has Dependency with nature as the condition of a village. Administratively, Namlea village is still a village form but on the social life of the village Namlea has become a small town with a still random growth.

The logical consequences of the urbanization process are one of them on land utilization[48]. Land becomes something that has 
a high value due to human needs. The impact of urbanization made the majority of Namlea's villagers convert land for day-today fulfillment and improved living standards[49].

The change of land function became dominant for the processing of economic resources into a domino effect of development occurring in Namlea village, a farmer's mindset that converts land to housing, offices and trade centers solely influenced Market needs for the provision of such locations[50]. The rational calculation to convert land is the impact of the change of society that leads to the urbanization process so that the function of the profession becomes a phenomenon that we can meet in Namlea village.

Diversification is not an accidental event, the change of land-land to serve as a center of Trade and office to be an evangelizing that land use orientation is no longer on the agricultural sector but has shifted Services and trade sectors [51]. The consequence that must be accepted is the increase in the selling price of agricultural products as well as the availability of staples sourced from agricultural land utilization.

\section{Conclusion}

The change in the regency of Buru has a direct impact on the development of Namlea village where the people who are displaced by indigenous peoples began to shift due to the increasing arrival of residents from outside Namlea village. The logical consequences of such conditions lead to changes in various sectors of life such as social economics that impact the interaction patterns and the fulfillment of needs. Changes in the community structure facilitate the urbanization process of Namlea village the faster with impacts that result in changes in the community's life system. The diversification of land is a direct impact of the temporary urbanization process, the orientation of diversification is more due to land needs and the opportunity to improve the quality of life of landowners and farmers. Increased price of agricultural products and the value of land selling as a condition of reduced production and land limitations.

\section{REFERENCES}

[1] A. Hasan Afandi and M. C. B. Umanailo, "Watudakon Citizens 'Social Conflict on Joker Toll Road Development in 2017 in Kesamben District, Jombang Regency," J. Soc. Sci. Res., vol. Special Is, no. 5, pp. 656-661, 2018.

[2] A. D. E et al., "The Existence of Waranggana in Tayub Ritual," Int. J. Sci. Technol. Res., vol. 8, no. 10, 2019.

[3] M. C. B. Umanailo, "Strategi Bertahan Hidup Petani Padi Gogo di Pulau Buru," J. Ekon. Pertan. dan Agribisnis, vol. 3, no. 1, pp. 50-58, Jan. 2019.

[4] M. C. B. Umanailo, "Consumption Diversification of Local Community," J. AGRISEP Kaji. Masal. Sos. Ekon. Pertan. dan Agribisnis, vol. 18, no. 1, pp. 61-74, Mar. 2019.

[5] R. Djibu, I. Shofwan, and M. C. Basrun, "Development of Andragogical Learning Model to Improve Life Skill for Teenagers Who Drop Out of School in Gorontalo City," Int. J. Sci. Technol. Res., vol. 8, no. 10, 2019.

[6] L. Rumkel, B. Sam, and M. C. B. Umanailo, "Village Head Partnership, Village Consultative Body and Customary Institution in Village Development," Int. J. Sci. Technol. Res., vol. 8, no. 8, pp. 1058-1063, 2019.

[7] M. C. B. Umanailo, M. Nawawi, and S. Pulhehe, "Konsumsi Menuju Konstruksi Masyarakat Konsumtif," Simulacra, vol. 1, no. 2, pp. 203-211, 2018.

[8] M. C. B. Umanailo, N. Handayani, A. Masniati, S. H. Makatita, and S. Lisaholit, "The Urbanization and Diversification of Farmland Namlea Village," Int. J. Sci. Technol. Res., vol. 8, no. 8, pp. 1049-1053, 2019.

[9] M. C. B. Umanailo, "Overview of Phenomenological Research," 2019, pp. 1-6.

[10] M. Apriyanto and M. C. B. Umanailo, "Decrease Polyphenols, Ethanol , Lactic Acid , and Acetic Acid during Fermentation with Addition of Cocoa Beans Innoculum," Int. J. Sci. Technol. Res., vol. 8, no. 9, 2019.

[11] M. C. B. Umanailo, "Studi pada Masyarakat Desa Waimangit Kabupaten Buru," SOCA, vol. 12, no. 12, pp. 63-74, 2018.

[12] S. Rachman, H. Hamiru, M. C. B. Umanailo, Y. Yulismayanti, and H. Harziko, "Semiotic Analysis of Indigenous Fashion in The Island of Buru," Int. J. Sci. Technol. Res., vol. 8, no. 8, pp. 1515-1519, 2019.

[13] M. Y. Zakaria, W. Malmia, A. Irmawati, N. F. Amir, and M. C. B. Umanailo, "Effect Mathematics Learning Achievement Motivation on Junior High School Students 1 Namlea," Int. J. Sci. Technol. Res., vol. 8, no. 10, 2019.

[14] M. C. B. Umanailo, "BUPOLO "Movement. 2019.

[15] S. Yusuf, M. C. B. Umanailo, R. N. Putri, D. Qhuril, M. Ely, and D. Darma, "Village Institution Relations in the Utilization of Village Funds in Namlea District," Int. J. Sci. Technol. Res., vol. 8, no. 8, 2019.

[16] M. C. B. Umanailo, R. Umanailo, R. Bugis, and A. T. Bon, "Empowerment Community in Buru Regency," in Proceedings of the International Conference on Industrial Engineering and Operations Management, 2019, pp. 2070-2075.

[17] M. S. J. Malisngorar et al., "Effect of Health Education Knowledge about Antenatal Care Mothers against Hamlet Land Shake the District Huamual West Seram Regency," Int. J. Sci. Technol. Res., vol. 8, no. 10, 2019.

[18] S. Prafitriyani, I. Magfirah, N. F. Amir, A. Irmawati, and M. C. B. Umanailo, "Influence of Emotional Intelligence on Mathematics Learning Outcomes of Class VII Middle School 9 Buru Students," Int. J. Sci. Technol. Res., vol. 8, no. 10, 2019.

[19] M. C. B. Umanailo, Masyarakat Buru Dalam Perspektif Kontemporer, vol. 53, no. 9. 2015.

[20] M. Muhasidah et al., "Healthy Food with Children Learning Achievements at Makassar City Elementary School," Int. J. Sci. Technol. Res., vol. 8, no. 10, 2019.

[21] M. C. B. Umanailo, Sosiologi Hukum, 1st ed. Namlea: FAM PUBLISHING, 2016.

[22] M. C. B. Umanailo and T. Yatno, Kajian dan Analisis Sosiologi Dalam Bentuk Kumpulan Essay, Makalah dan Opini. 2015.

[23] M. C. B. Umanailo, "Discourse on the Consumerist Community Consumption," J. Soc. Sci. Res., vol. 5, no. 54, pp. 1181-1186, Apr. 2019.

[24] A. Assagaf et al., "Educational Political Policy," Int. J. Sci. Technol. Res., vol. 8, no. 9, 2019.

[25] M. C. B. Umanailo et al., "Dominance of Economic Capital in Political," in Community Development, Decentralization \& Local Autonomy Politic \& Democracy, Fisip Universitas Brawijaya, 2018, pp. 1-120.

[26] R. I. Umasugi, C. C. Costa, M. Apriyanto, M. C. B. Umanailo, and N. Mufidah, "Dominance of Economic Capital in the Political," Int. J. Sci. Technol. Res., vol. 8, no. 9, 2019.

[27] M. C. B. Umanailo, IImu Sosial Budaya Dasar, 1st ed. Namlea: FAM PUBLISHING, 2015.

[28] M. C. B. Umanailo, Marginalisasi Buruh Tani Akibat Alih Fungsi Lahan, 1st ed. Namlea: Fam Publishing, 2016. 
[29] M. C. B. Umanailo, "Integration of Community Empowerment Models [Pengintegrasian Model Pemberdayaan Masyarakat]," Proceeding Community Dev., vol. 2, p. 268, Mar. 2019.

[30] M. C. B. Umanailo, I. Hamid, M. Nawawi, S. Pulhehe, S. Yusuf, and A. T. Bon, "Utilization of Qualitative Methods in Research Universities," in Proceedings of the International Conference on Industrial Engineering and Operations Management, 2019, pp. 2076-2081.

[31] M. C. B. Umanailo et al., "Comprehension To Village," 2018, pp. 1-2.

[32] M. C. B. Umanailo, "Overview Phenomenological Research," pp. 1-6.

[33] M. C. B. Umanailo, "Kalesang Dorp in Context De Bouw van Village."

[34] L. J. Buton et al., "The Effect of Nasa Liquid Organic Fertilizer Concentration and Planting Distance to Growth and Production of Beans," Int. J. Sci. Technol. Res., vol. 8, no. 9, 2019.

[35] W. Malmia et al., "Problem-Based Learning as an Effort to Improve Student Learning Outcomes," Int. J. Sci. Technol. Res., vol. 8, no. 9, 2019.

[36] W. Rumaolat, E. Dusra, I. S. Tunny, M. S. J. Malisngorar, S. Cahyawati, and M. C. B. Umanailo, "Relationship Diet and Regulate Blood Sugar in the Elderly with DM Type li in Waimital Village , Kairatu District , West Seram Regency," Int. J. Sci. Technol. Res., vol. 8, no. 10, 2019.

[37] A. L. Wabula, M. Musyawir, A. Irmawati, B. Rebel, D. M. Darajat, and M. C. B. Umanailo, "Maghrib Movement," Int. J. Sci. Technol. Res., vol. 8, no. 9, 2019.

[38] A. Rahmat, A. D. Gs, N. Djafri, I. Shofwan, and M. C. B. Umanailo, "The Influence of Family Leadership towards Adolescent Social Values in the City of Gorontalo," Int. J. Sci. Technol. Res., vol. 8, no. 10, 2019.

[39] M. Jannah, R. Widohardhono, F. Fatimah, D. K. Dewi, and M. C. B. Umanailo, "Managing Cognitive Anxiety through Expressive Writing in Student-Athletes," Int. J. Sci. Technol. Res., vol. 8, no. 10, 2019.

[40] N. S. Wisnujati et al., "Public Relations Management through Management by Objective," Int. J. Sci. Technol. Res., vol. 8, no. 10,2019

[41] M. C. B. Umanailo et al., "Cybercrime Case as Impact Development of Communication Technology That Troubling Society," Int. J. Sci. Technol. Res., vol. 8, no. 9, 2019.

[42] L. T. Muharlisiani et al., "The role of Customer Service through Customer Relationship Management ( CRM ) to Increase Customer Loyalty and Good Image," Int. J. Sci. Technol. Res., vol. 8, no. 10, 2019.

[43] R. Bugis et al., "Workers in the Namlea Market," Int. J. Sci. Technol. Res., vol. 8, no. 9, 2019.

[44] H. Hamiru et al., "Eucalyptus Oil Workers," Int. J. Sci. Technol. Res., vol. 8, no. 9, 2019.

[45] M. C. B. Umanailo, M. Yulisvestra, K. K. Oki, W. Mulyasari, and R. Ridwan, "The Thought of Emile Durkheim in the Contestation of Development in Indonesia," Int. J. Sci. Technol. Res., vol. 8, no. 8, 2019.

[46] A. Wael et al., "“ Bupolo 'Motion Reading," Int. J. Sci. Technol. Res., vol. 8, no. 9, 2019

[47] S. S. F. Assagaf et al., "Construction of the Village as a Development Shaft in the Island Buru," Int. J. Sci. Technol. Res., vol. 8, no. 9, 2019.

[48] B. S. Amanto, M. C. B. Umanailo, R. S. Wulandari, T. Taufik, and S. Susiati, "Local Consumption Diversification," Int. J. Sci. Technol. Res., vol. 8, no. 8, 2019.

[49] A. Ervina, D. Zulmi, R. Ariesta, Y. Aridawarni, A. Aminah, and M. C. B. Umanailo, "The Relationship of Patterns Use of Time and Income Family with Juvenile Delinquency in Junior High School Students at Lebak Distric," Int. J. Sci. Technol. Res., vol. 8, no. 10,2019

[50] M. Nawawi et al., "The Village Kalesang Program as a Poverty Alleviation Community," Int. J. Sci. Technol. Res., vol. 8, no. 10, 2019.

[51] B. Sam et al., "Female Feminism in the Customary Island of Buru," Int. J. Sci. Technol. Res., vol. 8, no. 8, 2019. 